\title{
GEOMORPHOLOGY AND SURFACE LANDFORMS DISTRIBUTION IN SELECTED ICE-FREE AREAS IN THE SOUTH SHETLAND ISLANDS, NORTHERN ANTARCTIC PENINSULA REGION
}

\author{
J. LÓPEZ-MARTÍNEZ ${ }^{*}$, T. SCHMID ${ }^{2}$, E. SERRANO ${ }^{3}$, \\ S. MINK $^{4,1}$, A. NIETO ${ }^{1}$, S. GUILLASO ${ }^{5}$ \\ 'Dpto. Geología y Geoquímica, Facultad de Ciencias, Universidad Autónoma de Madrid, Spain. \\ ${ }^{2}$ Dpto. de Medio Ambiente, CIEMAT, Madrid, Spain. \\ ${ }^{3}$ Dpto. Geografía, Universidad de Valladolid, Spain. \\ ${ }^{4}$ Instituto Geológico y Minero de España, Madrid, Spain. \\ ${ }^{5}$ Computer Vision and Remote Sensing Group, Technische Universität Berlin, Germany.
}

\begin{abstract}
Ice-free areas cover a small percentage of the land in the South Shetland Islands. However, they are significant as they contain ecosystems highly sensitive to environmental changes and are located within a region very much affected by global warming. These areas are dominated by periglacial, glacial, fluvial, and coastal processes and landforms, where permafrost is often present. Soil development is observed although vegetation cover is sparse and closely related to the geomorphology. The mapping and monitoring of ice-free areas is important as they are highly sensitive to climate change. The objective of this study was to characterize and map surface landforms in ice-free areas using traditional mapping methods as well as advanced remote sensing techniques. Geomorphological and topographical maps were initially obtained through field measurements and observations, and complemented with existing aerial photography at scales between 1:2000 and 1:25,000. Thereafter, satellite-borne data became available and were included in the methodology to further determine the distribution of the landforms. In the Antarctic environment, Synthetic Aperture Radar (SAR) provides the most reliable images as data can be obtained in any weather conditions as well as during the day and night. Fully polarimetric SAR RADARSAT-2 were used to determine seven different terrain classes representing surface landforms in ice-free areas around Maxwell Bay (King George Island). The SAR remote sensing techniques were successfully applied to identify different periglacial, fluvial, glacial, coastal, as well as lithological landforms. Field data from Fildes Peninsula were used to train a supervised classifier to map further areas around Maxwell Bay. In this case, the ice-free areas around Maxwell Bay clearly show the dominance of periglacial landforms and processes. Therefore, these techniques can be used to compare past and future results and to monitor areas affected by changing environmental factors and increasing human activities.
\end{abstract}


Geomorfología y distribución de formas de relieve en una selección de áreas libres de hielo en las Islas Shetland del Sur, región septentrional de la Península Antártica

RESUMEN. Las zonas descubiertas de hielo suponen una pequeña proporción del territorio de las Islas Shetland del Sur. Sin embargo, son importantes por contener ecosistemas muy sensibles a los cambios ambientales y estar situadas en una región que experimenta un rápido calentamiento. En dichas zonas son dominantes los procesos y formas de origen periglaciar, glaciar, fluvial y litoral, siendo frecuente la presencia de permafrost. Existe desarrollo de suelos, aunque el recubrimiento de vegetación es muy limitado y disperso, y ligado a la geomorfología. La cartografía y el seguimiento de las áreas libres de hielo tiene considerable importancia al ser muy sensibles al cambio climático. El objetivo de este trabajo es caracterizar y cartografiar las formas de la superficie del terreno en áreas libres de hielo, usando métodos tradicionales y técnicas avanzadas de teledetección. Varios mapas topográficos y geomorfológicos fueron elaborados inicialmente mediante mediciones y observaciones de campo, complementadas con la interpretación de fotografías aéreas a escalas de 1:2000 a 1:25.000. Posteriormente, al estar disponibles datos de satélite, se han incorporado en el método de trabajo para determinar la distribución de formas de relieve. En el ambiente antártico, el uso de Radar de Apertura Sintética (SAR) es particularmente útil al poder ser empleado con cualquier tiempo meteorológico y durante día y noche. Se han empleado datos polarimétricos de SAR RADARSAT-2 para determinar siete diferentes clases de superficie del terreno en áreas libres de hielo alrededor de Maxwell Bay (Isla Rey Jorge). Las técnicas de teledetección SAR pueden ser aplicadas con éxito para determinar diferentes formas de relieve de origen periglaciar, fluvial, glaciar, litoral y también litológicas. Los datos de la Península Fildes han sido usados para ensayar un clasificador supervisado para cartografiar otras áreas alrededor de Maxwell Bay. En este caso, las zonas libres de hielo alrededor de Maxwell Bay muestran claramente un predominio de las formas y procesos periglaciares. Por lo tanto, estas técnicas pueden ser usadas para comparar resultados anteriores y futuros, y hacer un seguimiento de las áreas afectadas por cambios ambientales o crecientes actividades humanas.

Key words: glacial, periglacial, coastal, geomorphological mapping, remote sensing, Antarctica.

Palabras clave: glacial, periglacial, costa, cartografía geomorfológica, teledetección, Antártida.

Received 20 February 2016 Accepted 16 March 2016

*Corresponding author: J. López-Martínez, Dpto. Geología y Geoquímica, Facultad de Ciencias, Universidad Autónoma de Madrid, 28049 Madrid, Spain. E-mail: jeronimo. lopez@uam.es 


\section{Introduction}

In the South Shetland Islands, within the northern Antarctic Peninsula region (Fig. 1), approximately $90 \%$ of the $4,700 \mathrm{~km}^{2}$ of the terrestrial surface is covered by ice. The icefree surfaces show a variety of landforms, mainly of glacial, periglacial, coastal and fluvial origin. The studied area is one of the most affected by global warming in the world over the past fifty years (Turner et al., 2005). Nowadays, the great majority of glaciers and snowfields are retreating (Cook et al., 2005), and the permafrost is melting leading to large-scale changes in surface hydrology and affecting ecosystems highly sensitive to environmental changes (Bockheim et al., 2013). Periglacial processes and landforms together with the presence of permafrost are among the most relevant geomorphological elements in the ice-free areas of the South Shetland Islands (López-Martínez et al., 2012). Freezing and thawing cycles within the soil favour the colonization process by vegetative propagation and create favourable conditions for the activity of the associated soil microorganisms. These conditions occur during the Austral summers, when snow cover is at a minimum (Tin et al., 2014). However, soil is highly vulnerable in the Antarctic environment because of the low temperatures, general absence of vegetation and soil biota (Campbell and Claridge, 1987). Soils in the South Shetland Islands show differences with those of Antarctic continental regions as a consequence of different climatic conditions that determine edaphic processes and soil development (Balks et al., 2013). Relationships between soils and geomorphology have also been shown throughout the South Shetland Islands (Michel et al., 2014).

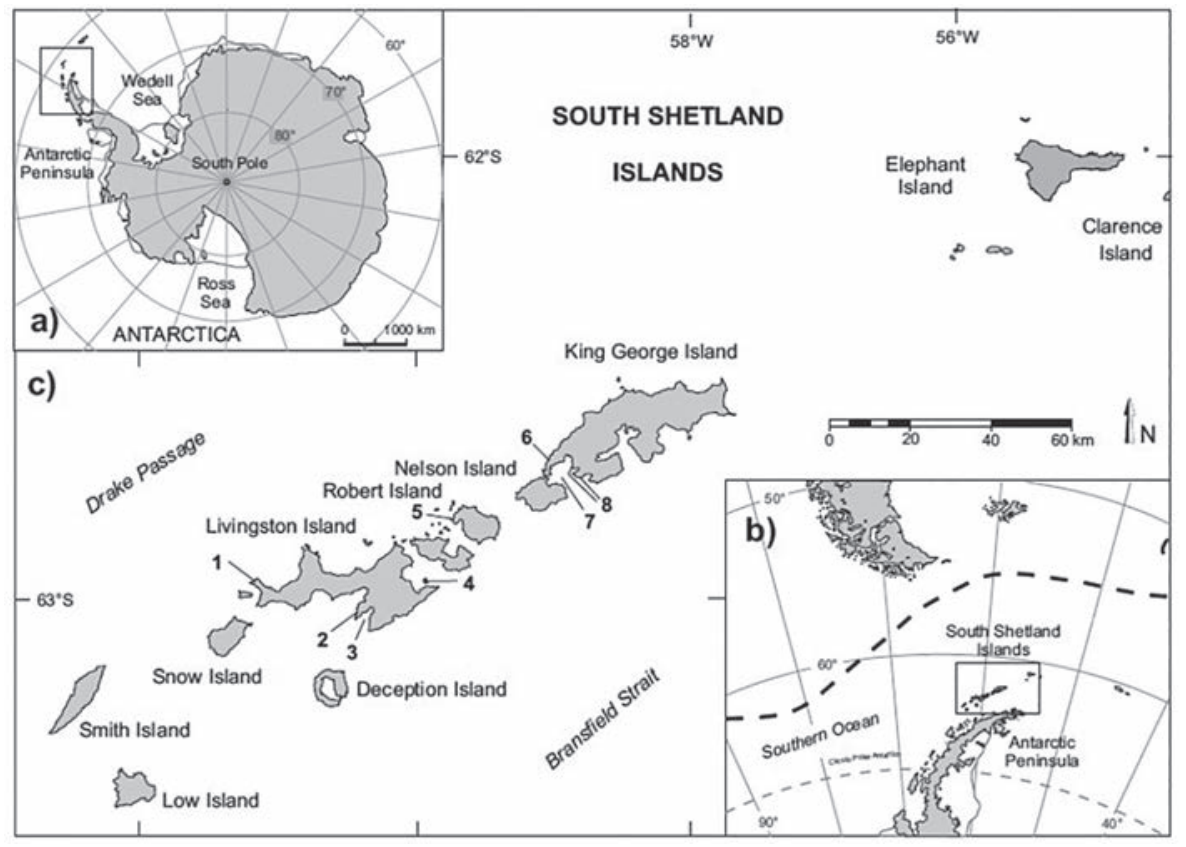

Figure 1. Location of the ( $a, b)$ South Shetland Islands in Antarctica and (c) the places mentioned in the text. 1: Byers Peninsula, 2: Hurd Peninsula, 3: False Bay, 4: Half Moon Island,

5: Coppermine Peninsula, 6: Fildes Peninsula, 7: Maxwell Bay, 8: Barton and Weaver peninsulas (Potter Peninsula is to the Southeast of Barton Peninsula). 
Since ice-free areas are highly sensitive to climate change, their mapping and monitoring is an important work. Numerous studies carried out in the South Shetland Islands include the periglacial environment, where patterned ground, gelifluction, cryoclastic and cryoturbation processes, slope processes, and permafrost and active layer are the main focus (John and Sudgen, 1973; Simonov, 1977; Barsch et al., 1985; Vtyurina and Moskalevskiya, 1985; Xie, 1988; Cui et al., 1989; Qingsong, 1989; Martínez de Pisón et al., 1991, Zhu et al., 1996; Jeong, 2006; Serrano and López-Martínez, 1997a, 1997b, 1998, 2000, 2012; Serrano et al., 2002a, 2002b, 2008; López-Martínez et al., 2012). Also, some studies have also focussed on soils and cryogenic processes (Blümel and Eitel, 1989; Ye and Tianjie, 1996; Chen and Blume, 1999; Chen et al., 2000).

During the last decade a considerable amount of soil, permafrost and geomorphological studies have been carried out in this region which is becoming warmer and wetter (Michel et al., 2006, 2012, 2014; Navas et al., 2006, 2008; Simas et al., 2006, 2007, 2008; Schaefer et al., 2007; Serrano et al., 2008; Vieira et al., 2008, 2010, 2014; Francelino et al., 2011; López-Martínez et al., 2012; Moura et al., 2012; Balks et al., 2013; Bockheim et al., 2013; Oliva and Ruiz-Fernández, 2015; Simas et al., 2015; Oliva et al., 2016). The relationship between landforms and soil distribution (Balks et al., 2013; Michel et al., 2014) and the distribution and changes of vegetation related to ice-free areas (Cannone and Guglielmin, 2010; Pereira and Putzke, 2013; Guglielmin et al., 2014; Vieira et al., 2014) have been studied in detail in some areas.

Geomorphological mapping is a useful tool for studying landscape evolution and locate recent and active processes in Antarctic ice-free areas. There are several of these maps for the whole Antarctica region and also for the studied region (Baroni et al., 1997; Bruschi et al., 1997). In some areas of interest in which appropriate topographic maps did not exist, these were elaborated for supporting the geomorphological and geological mapping that was going to be carried out (SGE-UAM-BAS, 1992; SGE-UAM, 1993; CGE-UAM-UFRJ, 2005). Our research group has compiled geomorphological maps at scales between 1:25,000 and 1:10,000 for some of the largest and more relevant ice-free areas of the South Shetlands archipelago, as Byers Peninsula on Livingston Island (LópezMartínez et al., 1995, 1996b), Deception Island (López-Martínez et al., 2000), Barton and Weaver peninsulas on King George Island (López-Martínez et al., 2002a); Fildes Peninsula on King George Island (Serrano and López-Martínez, 2012). Besides, many geomorphological sketch maps have been published in articles about the geomorphology of different areas of the South Shetland Islands (Martínez de Pisón et al., 1991; LópezMartínez et al., 1992, 1996a, 2012; Serrano and López-Martínez, 1997a, 1997b, 1998).

These maps have been prepared using traditional methods, including fieldwork and aerial photography interpretation. Nowadays, with advanced remote sensing techniques, optical and microwave satellite data can be used to obtain adequate and repeated data for characterising and monitoring surface covers in the ice-free areas (Magagi and Bernier, 2003; Koch et al., 2009; Vieira et al., 2014). However, because the dense cloud cover in Maritime Antarctica limits the application of optical sensors, microwave sensors are usually the most appropriate option (Mora et al., 2013). The use of Synthetic Aperture Radar (SAR) data has been implemented within the Antarctic region in many studies 
(Engeset and Weydahl, 1998; Jezek, 1999; Jezek et al., 2003; Koch et al., 2008; Schmid et al., 2012) and surface mapping has been carried out with data obtained from the space-borne ALOS PALSAR, RADARSAT-2 and TerraSAR X (Koch et al., 2008, 2009; Schmid et al., 2012, 2015; Guillaso et al., 2015).

The objective of this study was the characterization and mapping of surface landforms in ice-free areas using traditional mapping methods and as data from newly developed satellite-borne sensors and advanced remote sensing techniques become developed, using these to compliment and further develop the mapping processes carried out in selected study areas of the South Shetland Islands. These methods include field data obtained during several campaigns, in situ mapping, and fully polarimetric SAR C band RADARSAT- 2 data to extract the information that was used to characterize and monitor the identified surface landforms.

\section{Geographical, geological and climatic setting}

The South Shetland Islands are located between $61^{\circ} 59^{\prime} \mathrm{S}$ to $63^{\circ} 20^{\prime} \mathrm{S}$ and $57^{\circ} 40^{\prime} \mathrm{W}$ to $62^{\circ} 45^{\prime} \mathrm{W}$, about $120 \mathrm{~km}$ north of the Antarctic Peninsula, between the Drake Passage and the Bransfield Strait (Fig. 1). There are 11 major islands and several minor ones, with a total area of $4,700 \mathrm{~km}^{2}$. The South Shetland Islands extend about $450 \mathrm{~km}$ from Smith and Snow islands in the west-southwest, to Elephant and Clarence islands in the east-northeast.

The archipelago forms the southern part of the Scotia Arch and is composed of Late Palaeozoic to Quaternary sedimentary, metamorphic, plutonic and volcanic rocks. The formation of the South Shetland Islands began in the Mesozoic due to subduction processes associated with the convergence of the Phoenix and Antarctic plates. During successive phases, represented by basalt lavas and multiple intrusions in between, the main arc-building period went through to the Late Tertiary, which is characterized by emplacements and eruption of magmas (Smellie et al., 1984). The widening of the Bransfield Basin started about $4 \mathrm{My}$ ago when the subduction ended and a rollback process and other tectonic stresses started, causing compression processes in the archipelago (Barker et al., 1991; González-Casado et al., 2000). The area shows Quaternary volcanic activity, with Deception Island being the most important and active volcano, with its last eruption in 1970 (López-Martínez et al., 2002b).

Some islands have a mountainous relief, such as Smith Island (Mt. Foster, $2012 \mathrm{~m}$ a.s.l.) and Livingston Island (Mt. Friesland, $1770 \mathrm{~m}$ a.s.l.), whereas other islands are lowlying and flat, such as Snow Island (305 $\mathrm{m}$ a.s.1.), Low Island (180 m a.s.1.), Robert Island, (385 m a.s.1.) and Nelson Island (332 $\mathrm{m}$ a.s.1.). Only $10 \%$ of the $4,700 \mathrm{~km}^{2}$ of the emerged land are ice-free surfaces. Most of these surfaces are peninsulas, capes, points and narrow coastal fringes characterized by extended raised platforms of marine origin that in some cases are located up to $250 \mathrm{~m}$ a.s.l. (Arche et al., 1996; Serrano and LópezMartínez, 2004, 2012).

The climate of the South Shetland Islands is cold maritime, with summer rains, high cloudiness and a moderate thermal range (Schwerdtfeger, 1970; Simonov, 1977; Bañón, 1992; Vaughan et al., 2003). Common weather types are connected with cold 
and dry periods dominant during winter, and the influence of the circumpolar trough of low pressure during summer, with strong westerly wind and wet and relatively warm air masses (King and Turner, 1997; Rasmussen and Turner, 2003). The mean annual air temperature at sea level is around $-2^{\circ} \mathrm{C}$, and daily summer temperatures are usually higher than $0^{\circ} \mathrm{C}$. These conditions favour snow cover melting and freeze-thaw cycles during summer. The annual number of air freeze-thaw cycles is 120 to 122 in Fildes Peninsula, King George Island (Blümel and Eitel, 1989; Qingsong, 1989; Hall, 1992a, b, 1993). The annual precipitation can vary from 476 to $773 \mathrm{~mm} \mathrm{a} \mathrm{a}^{-1}$ on Fildes Peninsula (Schwerdtfeger, 1970; Simonov, 1977; Rakusa-Suszczewski, 1993, 2002; Bello et al., 1996) to between 500 to $800 \mathrm{~mm} \mathrm{a}^{-1}$ on Byers Peninsula (Bañón et al., 2013). The summer precipitations reach maximums between 100 and $159.2 \mathrm{~mm}$ and the mean relative air humidity is between 80 and 90\% (Schwerdtfeger, 1970; Simonov, 1977; Bañón, 1992; Rakusa-Suszczewski, 1993, 2002; Bello et al., 1996; Bañón et al., 2013). These conditions imply high water availability during the austral summer. At present, the maritime Antarctica experiments extreme climate variability and significant warming with Main Annual Air Temperature (MAAT) having increased between 1 and $3^{\circ} \mathrm{C}$ over the past 50 years (Turner et al., 2005). King and Comiso (2003) pointed out the importance of this warming on environmental changes; because the $0^{\circ} \mathrm{C}$ isotherm passes close to the region, a small temperature rise implies increasing melt rates of glaciers and thermal changes on ground, permafrost and hydrological conditions.

\section{Material and methods}

Over the last two decades, mapping of the ice-free areas for the different study sites was carried out during several expeditions in which measurements and observations of landforms and features were obtained directly in the field. The most recent campaign took place during the austral summer of 2012/2013 where a total of 27 study sites were selected according to their geomorphological characteristics throughout Fildes Peninsula. Additionally, aerial photography and satellite-borne multispectral data have also been used when data was available, to complement the mapping of the areas of interest. However, it is difficult to obtain images in the spectral optical range (400 to $2500 \mathrm{~nm}$ ) with sufficient quality as the cloud cover in the Antarctic region can be persistent. Therefore, remote sensing data, which is not affected by cloud cover, such as Synthetic Aperture Radar (SAR) data were acquired from the RADARSAT-2 sensor. This included fully polarimetric data for the Maxwell Bay area for 8 March 2014. The data and results generated from the field campaigns, aerial photography and SAR images together with ancillary data such as meteorological and topographic data were compiled in a geo-referenced data base using a Geographic Information System (Fig. 2). This makes it easier to combine data sets and to characterize and monitor study sites of interest.

\subsection{Field mapping and complementary use of aerial photographs}

Geomorphological mapping is an effective tool for representing the location of landforms and to analyze their spatial distribution. To study landforms of the ice-free areas and their distribution in the South Shetland Islands, geomorphological maps at 


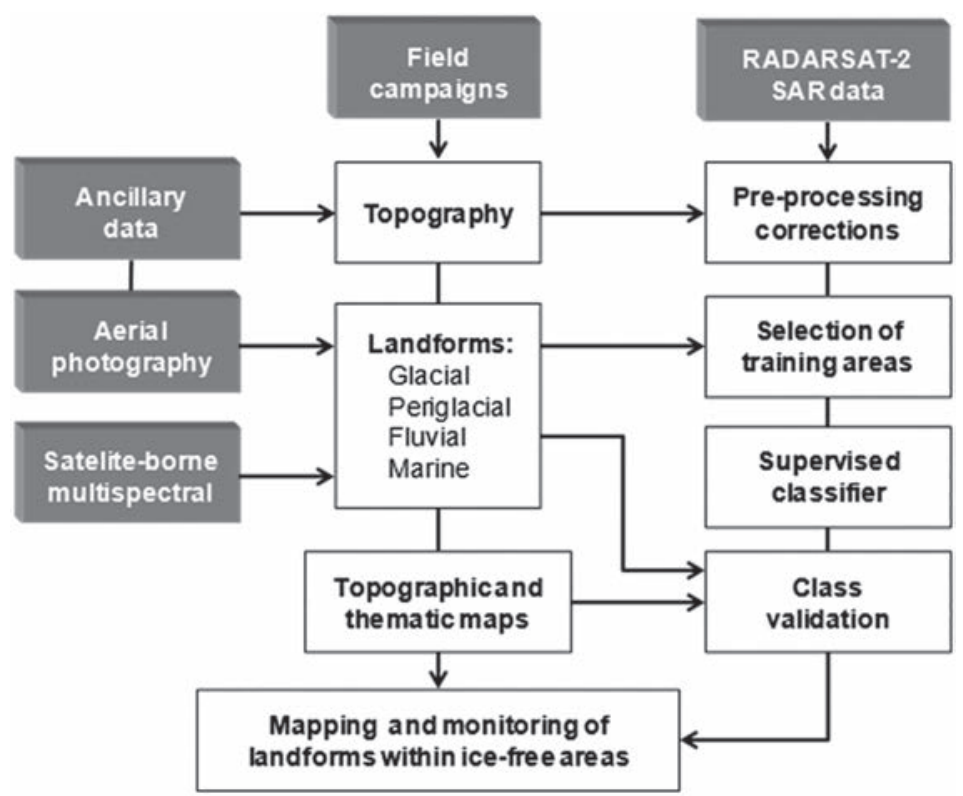

Figure 2. Methodology for mapping landforms in ice-free areas

a scale between 1:25,000 and 1:10,000 were generated by members of the group for the areas of Livingston Island, Deception Island, King George Island and Elephant Island. All the maps were produced with information and data from fieldwork as well as from aerial photographs. Field work included slope transects, stratigraphic sections, lake cores, direct sounding and vertical electrical sounding for identifying and mapping landforms. Elevation points were obtained in the field using the global positioning system for creating a topographic base map and a digital elevation model (DEM). Periglacial, glacial, coastal and fluvial landforms and processes were studied in the ice-free areas in order to map the different geomorphological features as a series of thematic maps.

\subsection{SAR remote sensing techniques to map the ice-free areas}

The fully polarimetric SAR data files were initially pre-processed which included extraction from the original data set, radiometric calibration and conversion of the data set to a complex ( $3 \times 3)$ coherency matrix (T3) and applying a space-domain averaging of the data using the Sentinel-1 Toolbox (S1TBX, 2014). After importing the data into PolSARPro (Pottier, 2010), a bilateral polarimetric speckle filter (D'Hondt et al., 2013) was applied to allow the extraction of polarimetric features. Polarimetric features were derived from the analysis of the coherency matrix and different polarimetric parameters are extracted based on eigenvalues and eigenvectors (Lee and Pottier, 2009). Polarimetric parameters were extracted from the polarimetric decompositions according to An Cui Yang, Freeman, H/A/Alpha, Lexicographic Basis, Pauli, Praks \& Colin, Van Zyl and Yamaguchi (Lee and Pottier, 2009), which resulted in a total of 85 parameters. 
The physical structure of each surface cover related to a landform influences the backscattering of the electromagnetic radiation received by the radar and is used to determine the polarimetric parameters. Therefore, these parameters were used to distinguish surface landforms according to the different scattering mechanisms (SM) that occurred during data acquisition. The polarimetric parameters were geocoded in order to associate the images with field reference sites from the study area. The geocoding and terrain corrections were carried out using site specific DEM maps that were generated from the field data as well as freely available ASTER 1sec GDEMs and the Sentinel-1 Toolbox. A final geometric correction was applied with a maximum of 20 Ground Control Points (GCPs) taken from topographical maps of the different study sites. The level of accuracy of the geo-referencing was determined by a root mean square error of less than 0.5 pixel and the spatial image resolution resulted in $12.5 \mathrm{~m}$. Masks were applied to eliminate the sea and glacier areas surrounding the different peninsulas and islands before carrying out further image processing.

A supervised classification was carried out applying the Support Vector Machine (SVM) algorithm (Foody and Mathur, 2004a) and using the polarimetric parameters as input that contain backscattering information for the ice-free study areas. One of the main advantages using the SVM classifier is that it performs well even when the amount of data is limited (Foody and Mathur, 2004b). The SVM was selected with the Gaussian Radial Basis Function (RBF) kernel and a 10-fold cross-validation option using the e1071 package (Dimitriadou et $a l ., 2005)$ that was operated in the R language (R Development Core Team, 2004). The inputs of the polarimetric parameters were stacked and scaled to a range of $0-1$, to avoid that attributes in greater numeric ranges dominate over those in smaller numeric ranges (Hsu et al., 2010). The study sites representing different classes were used for training the SVM classifier. Each class was represented by 8 to 14 training sites that were selected from field data from test sites located on Fildes Peninsula and from the geomorphological map of Fildes Peninsula (Serrano and López-Martínez, 2012). During the last field campaign, study sites were already chosen so that the corresponding surface landforms could be identified taking into account the spatial resolution of the fine polarimetric image obtained with RADARSAT-2.

\section{Spatial distribution of surface landforms in ice-free areas}

\subsection{Mapping results in selected areas of the South Shetland Islands}

The types and distribution of geomorphological features in the ice-free areas of the South Shetland archipelago has been obtained by means of the geomorphological maps and local studies carried out by our group.

In the studied area, relief features are in some cases consequence of the existing lithology and geological structure. This is very clear in the case of volcanic plugs and dikes (e.g. on Byers Peninsula). Fractures and lineaments analysis have been determined using field data measurements and aerial photographs and satellite data interpretation (e.g. Mink et al., 2015). By studying relatively large ice-free areas, like Byers Peninsula $\left(60.6 \mathrm{~km}^{2}\right)$, the largest ice-free area in the region, relationships between drainage streams development and the fractures network have been identified, as well as its relation with the time and mode of deglaciation (Mink et al., 2014). 
The ice-free areas have been shaped by glaciers, and therefore glacial landforms are dominant (e.g. John and Sudgen, 1971; Sugden and John, 1973), together with coastal forms, marine platforms, raised beaches and present day beaches. As a result, structural, glacial and marine landforms systems make up the landscape.

Regarding periglacial landforms and processes, different morphogenetic subsystems, such as weathering, gravity, frost creep, active layer related, nivation and thermokarst, have been identified (Table 1). Besides the general geomorphological maps compiled by our group for Byers Peninsula, Fildes Peninsula, Barton Peninsula and Deception Island, simplified maps containing periglacial and glacial information were prepared for ice-free areas on Livingstone Island, King George Island and Elephant Island (LópezMartínez et al., 2012). A series of slope transects have allowed the recognition of landforms and processes involved in debris transfer systems (e.g. Serrano et al., 2002a). Active landforms were differentiated from inactive ones by means of field evidence. For instance, the existence of ice segregation, visible on the surface and profiles made on platforms, slopes and moraines on Hurd and Byers peninsulas and on Elephant Island, together with the absence of plant colonization provides information on the activity of patterned ground, stone fields and debris talus.

Table 1. Main periglacial landforms and processes mapped in ice-free areas of the South Shetland Islands.

\begin{tabular}{|c|c|c|c|c|c|c|}
\hline $\begin{array}{l}\text { Geomorphic } \\
\text { system }\end{array}$ & Landforms & $\begin{array}{l}\text { Topography } \\
\text { Orientation }\end{array}$ & $\begin{array}{c}\text { Active } \\
\text { Layer } \\
\text { Depth (cm)a }\end{array}$ & $\begin{array}{c}\text { Main } \\
\text { processes }\end{array}$ & $\begin{array}{l}\text { Altitude } \\
\text { m a.s.l. }\end{array}$ & Texture \\
\hline \multirow[t]{5}{*}{$\begin{array}{l}\text { Permafrost and } \\
\text { active layers }\end{array}$} & $\begin{array}{l}\text { Patterned ground: } \\
\text { Polygons, circles and } \\
\text { stone stripes }\end{array}$ & $\begin{array}{l}\text { - Platforms } \\
\text { - Gentle slopes } \\
\text { - Poor drainage }\end{array}$ & $20-50$ & $\begin{array}{l}\text { Cryoturbation } \\
\text { Frost heave } \\
\text { Frost creep }\end{array}$ & $10->200$ & $\begin{array}{l}\text { Fines and coarse, } \\
\text { gravels and pebbles. }\end{array}$ \\
\hline & $\begin{array}{l}\text { Stone fields } \\
\text { Frost mounds }\end{array}$ & $\begin{array}{l}\text { - Platforms } \\
\text { - Flat and gentle slopes } \\
\text { - Poor drainage }\end{array}$ & $20-50$ & $\begin{array}{l}\text { Frost heave } \\
\text { Cryoturbation }\end{array}$ & $10-18$ & Fines particles \\
\hline & $\begin{array}{l}\text { Rock glaciers } \\
\text { and protalus lobes }\end{array}$ & - Slopes N and NW & -- & Frost creep & $0-300$ & $\begin{array}{l}\text { Coarse, gravels, pebbles } \\
\text { and blocks }\end{array}$ \\
\hline & Block fields & $\begin{array}{l}\text { - Platforms } \\
\text { and flat areas }\end{array}$ & $20-50$ & $\begin{array}{l}\text { Frost creep } \\
\text { Gelifluction }\end{array}$ & $40-300$ & $\begin{array}{l}\text { Coarse, gravels, pebbles } \\
\text { and blocks }\end{array}$ \\
\hline & Block streams & - Gentle slopes & $20-50$ & $\begin{array}{l}\text { Frost cracking } \\
\text { Frost heave } \\
\text { Cryoturbation }\end{array}$ & $20-300$ & $\begin{array}{l}\text { Coarse, pebbles and } \\
\text { blocks }\end{array}$ \\
\hline \multirow[t]{2}{*}{$\begin{array}{l}\text { Seasonal frozen } \\
\text { ground and } \\
\text { permafrost }\end{array}$} & $\begin{array}{l}\text { Debris talus } \\
\text { Debris cones }\end{array}$ & $\begin{array}{l}\text { - Slopes, } 25^{\circ} \text { to } 45^{\circ} \\
\mathrm{N} \text { and NE }\end{array}$ & $\begin{array}{l}\text { No permafrost } \\
\text { To } 20-150\end{array}$ & $\begin{array}{l}\text { Fall } \\
\text { Snow avalanches } \\
\text { Frost cracking }\end{array}$ & $0-300$ & $\begin{array}{l}\text { Coarse, gravels, pebbles } \\
\text { and blocks }\end{array}$ \\
\hline & $\begin{array}{l}\text { Ploughing blocks } \\
\text { Gelifluction lobes } \\
\text { Debris lobes } \\
\text { Geometric clast } \\
\text { Laminated cracking } \\
\text { Tors } \\
\text { Cryoplanation terraces }\end{array}$ & $\begin{array}{l}\text { - Moderate to strongly } \\
\text { sloping ground } \\
\text { - Gentle slopes to } \\
\text { moderate sloping } \\
\text { ground }\end{array}$ & $20-100$ & $\begin{array}{l}\text { Gelifluction } \\
\text { Solifluction } \\
\text { Cryonival } \\
\text { Frost cracking } \\
\text { Frost heave } \\
\text { Cryoturbation }\end{array}$ & $20-300$ & $\begin{array}{l}\text { Coarse, pebbles and } \\
\text { blocks } \\
\text { Coarse }\end{array}$ \\
\hline \multirow[t]{3}{*}{ Cryonival } & Nivation hollows & \multirow{3}{*}{$\begin{array}{l}\text { - Platforms } \\
\text { - Slopes }>5^{\circ}\end{array}$} & \multirow[t]{3}{*}{---} & \multirow[t]{3}{*}{ Nivation } & \multirow[t]{3}{*}{$0-300$} & \multirow[t]{3}{*}{ Fine and coarse particles } \\
\hline & Protalus rampart & & & & & \\
\hline & Snow pavementss & & & & & \\
\hline
\end{tabular}


The landform geometry of rock glaciers, protalus lobes, nivation features and block streams, or the fresh and recent appearance of some features indicate that active periglacial processes are present in several places. The rock glaciers and protalus lobes lose the front angle and surface forms, nivation landforms are modified quickly losing the profile and fines when they are inactive, and block streams are washed by water and transformed in block accumulations on slopes, in some cases colonized by lichens. The presence of permafrost below an active layer has been detected at depths between $20 \mathrm{~cm}$ and more that $1.5 \mathrm{~m}$, by direct sounding with rods and pits on Deception Island, Elephant Island, and Livingston Island (on Byers and Hurd peninsulas). Vertical electrical sounding has been used for this purpose on Hurd Peninsula (Serrano et al., 1996; Bergamín et al., 1997; López-Martínez and Serrano, 2002).

In some cases, poor drainage is related to the presence of permafrost on platforms and gentle slopes, as observed with pits and rods at Fildes Peninsula (King George Island), Hurd and Byers peninsulas (Livingston island), and Coppermine Peninsula (Robert Island), as well as in different places on Deception and Elephant islands. The availability of water during the spring-summer melting period and autumn refreezing together with summer thermal changes implies dynamic processes in the active layer.

The studies carried out in different places of the archipelago mentioned above, show that Quaternary sea level changes are responsible for some of the main relief features in the region. This is the case of the extensive presence of Holocene raised beaches (at less than $21 \mathrm{~m}$ a.s.1.) and a series of higher pre-Holocene raised marine erosive platforms at different altitudes, with flat topographies limited by cliffs (e.g. López-Martínez et al., 1992; Arche et al., 1996; Martínez de Pisón et al., 1996; Berkman et al., 1998; Hall, 2010).

The highest Holocene raised beaches at about $20 \mathrm{~m}$ and the stratigraphic sections and lake cores, suggest that initial Holocene deglaciation in the archipelago may have occurred about more than 9,000 yr BP (Hall, 2010). A double high stand of relative sea level during the mid-Holocene at 9000 and $7500 \mathrm{yr}$ BP has been related to a temporary pause in ice retreat (7.2 ka BP), falling from $7 \mathrm{ka} \mathrm{BP}$ to present in response to continued glacial unloading and isostatic rebound, with a possibly acceleration during the last 500 years (Hall, 2010; Watcham et al., 2011).

Evidence of ice retreat phases has been identified and mapped in most of the studied icefree areas. In several places, like False Bay coast (Livingston Island) and Coppermine Peninsula (Robert Island), we have identified two Holocene glacial pulses by means of moraines and Holocene raised beaches relationships. Studies on the glacial history of the South Shetland Islands point out the deglaciation of some capes and peninsulas at around 11 to $9.5 \mathrm{ka} \mathrm{BP}$. On Fildes Peninsula the deglaciation begun between 11 and $9 \mathrm{ka}$ ago (Watcham et al., 2011), and on King George Island (Potter Peninsula) between 11.9 and 5.9 ka while on Byers Peninsula an age of 8.3-5.9 ka has been determined (Toro et al., 2013, Oliva et al., 2016). A regional advance between 6 and $4.5 \mathrm{ka} \mathrm{BP}$ (Hall, 2010; Michalchuck et al., 2009) has been detected after a period with less cold conditions between 8.2 and $5.9 \mathrm{ka}$ (Milliken et al. 2009). Both periods involve the development of periglacial and permafrost environments on the ice-free areas. Finally, a last small advance of ice domes and ice occupied the cirques during the Little Ice Age. These ages frame the beginning of periglacial activity within these areas. 


\subsection{Surface landforms surrounding Maxwell Bay}

The data obtained using SAR remote sensing techniques depends on the signal of back scattering that is related to the different scattering mechanisms (SM) (Lee and Pottier, 2009). It is therefore important to relate this signal received by the SAR sensor to the physical properties of the main surface landforms and features that are identified in the ice-free areas surrounding Maxwell Bay. Using the field information from the study sites on Fildes Peninsula and locating the corresponding position of these sites within the SAR data, seven different classes were determined. The classification is based on the dominant geomorphological characteristics, the topography and the physical properties of the surface landforms such as texture and structure. For each class, the relation with the radar SM is also indicated.

- Class 1: Gravel and sand deposits of present day and Holocene beaches, and colluvium deposits. The topography includes flat and depression areas $(<2 \%)$ as well as the toeslope where material is deposited. The physical properties are coarse sediments to rounded pebble sized stones. Surface and volume SM are identified as a result of the low to medium entropy and high anisotropy.

- Class 2: Pavements that are in flat and slightly sloping areas $(<2 \%)$. The surface cover is regular and consists of fine sediments, gravel and angular stones. The low and medium entropy leads to surface and volume SM.

- $\quad$ Class 3: Stone fields within slightly sloping to undulating terrain (2-8\%). They consist of fractured rocks with a heterogeneous distribution. There is low entropy and anisotropy resulting in surface SM.

- Class 4: Patterned ground found in flat or undulating topography with a maximum slope of $30 \%$. It consists of a wide area occupied by geometric (hexagons or circles) figures with a 1 to 3 m diameter and a sorted distribution of clasts up to about $30 \mathrm{~cm}$ in diameter. These areas have an entropy and low anisotropy causing random SM.

- $\quad$ Class 5: Glacial till deposits and rock outcrops. There are crests separated by depressions, abrupt changes with steep slopes (>30\%), and cliffs. This includes ice cored moraine sediments with varying rock size and exposed rock surfaces with debris slopes at the footslope. The SAR data shows medium and high entropy indicating volume and multiple SM.

- $\quad$ Class 6: Lakes and flooded areas present at sea level to upper raised platforms. They are flat surfaces and are very smooth in calm conditions. They have low entropy with surface SM.

- $\quad$ Class 7: Ice and snow cover on flat or undulating topography with a maximum slope reaching $30 \%$. It has a smooth surface of ice or snow cover, which is highly season-dependent. A low to medium entropy is obtained leading to surface SM. 
The geomorphological features of the classes 1 to 4 have a heterogeneous physical structure influencing the backscattering signal received by the radar for the individual surface landforms. This includes variations in the stone size, surface structure of these covers (smooth or rough) and a possible presence of sparse to moderate vegetation cover. Therefore, certain features may be represented by more than one class. The physical surface variation of materials and their distribution over a small area can vary significantly as is common for these first four classes. The surfaces such as glacial till and rock outcrops (class 5) and lakes and flooded regions, ice and snow cover (classes 6 and 7) have well defined scattering mechanisms and make their identification in most cases straight forward. A further point to consider is that for these areas it is logistically rare to have fieldwork and data with remote sensors acquired at the same moment. Therefore, to account for additional influences such as surface wetness and possible snow cover at the given time of data acquisition, information is retrieved from the nearest meteorological stations that are often near or next to stations.

The distribution of the seven classes were obtained in the ice-free areas surrounding Maxwell Bay (Fig. 3) (Schmid et al., 2015).

The total terrestrial area of the Radarsat-2 image around Maxwell Bay is $208.1 \mathrm{~km}^{2}$. The total ice-free area that has been identified is $55.3 \mathrm{~km}^{2}$ and the areas occupied by glaciers and ice fields are $111.9 \mathrm{~km}^{2}$ for King George Island and $40.9 \mathrm{~km}^{2}$ for Nelson Island, which brings the total area to $152.8 \mathrm{~km}^{2}$ that is within the RADARSAT-2 footprint. The spatial distribution of the surface landforms is a complex mosaic (Fig. 3).

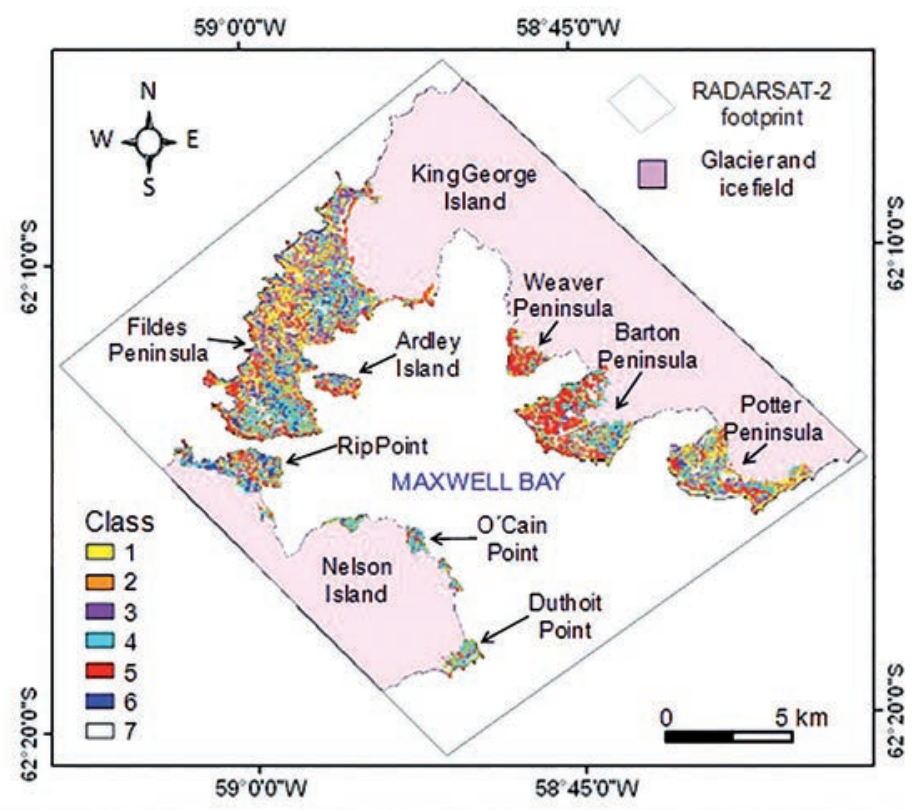

Figure 3. Supervised classification of the ice-free areas surrounding Maxwell Bay (King George and Nelson islands). See Fig. 1 for location. Classes: 1 - Gravel and sand deposits; 2 - Pavements; 3 - Stone fields; 4 - Patterned ground; 5 - Glacial till deposits and rock outcrops; 6 - Lakes and flooded areas; and 7 - Ice and snow cover on 
The biggest ice-free areas are related to Fildes Peninsula, followed by Barton Peninsula and Potter Peninsula (Table 2). The gravel and sand deposits of present day and Holocene beaches, and colluvium deposits (class 1) occupy an area of $7.7 \mathrm{~km}^{2}(13.9 \%)$. As expected, colluvium deposits are found throughout the study area and drainage areas are the prime location for these types of deposits. Periglacial features are dominant features on Fildes Peninsula, Potter Peninsula and Nelson Island. Pavements (class 2) are the most representative for Fildes Peninsula. In the case of Nelson Island, ice-free areas along the coast have been grouped together and the patterned grounds (class 4) are the most representative surface landforms. It is to point out that the physical structure of the pavement, stone field (class 3) and patterned ground are similar. This means that the backscattering information received by the SAR sensor is similar and separating these surfaces is more difficult. Patterned ground can also vary widely in size from sub metric size to tens of meter. Therefore, the capability of the identification of patterned ground lies mainly in the size of the surface structure and will range from feature with about 10 to $25 \mathrm{~m}$. Smaller or larger patterned ground structures will be more likely to be related to the pavement and stone field classes. Throughout the ice-free areas, the pavements (class 2) and patterned grounds (class 4) are the most widely distributed with a $12.3 \mathrm{~km}^{2}$ $(22.3 \%)$ and $11.1 \mathrm{~km}^{2}(20 \%)$ coverage, respectively. In the case of Barton Peninsula and Weavers Peninsula, glacial till and rock outcrop (class 5) are the most dominant surface landforms. The common characteristics of these features are the abrupt surface changes and the size of the physical structure $(>10 \mathrm{~m})$. These structures include boulders, massive igneous bodies, scarps and crests of hills that may have sizeable crevices and clefts. Lakes and flooded regions (class 6) and ice and snow cover (class 7) with a total of $3.1 \mathrm{~km}^{2}$ and $4.6 \mathrm{~km}^{2}$ occupy the smallest surface of the ice-free areas and are season dependent. Furthermore, the snow cover that is present at the moment of the SAR data acquisition depends largely on the meteorological conditions.

Table 2. Total surface area occupied by each class and for the different peninsulas and islands of the ice-free areas within Maxwell Bay. Classes: 1 - Gravel and sand deposits; 2 - Pavements; 3 - Stone fields; 4 - Patterned ground; 5 - Glacial till deposits and rock outcrops; 6 - Lakes and flooded areas; and 7 - Ice and snow cover on.

\begin{tabular}{|c|c|c|c|c|c|c|c|}
\hline Class & $\begin{array}{c}\text { Fildes } \\
\text { Penins. } \\
{\left[\mathrm{km}^{2}\right]}\end{array}$ & $\begin{array}{c}\text { Weavers } \\
\text { Penins. } \\
{\left[\mathrm{km}^{2}\right]}\end{array}$ & $\begin{array}{c}\text { Barton } \\
\text { Penins. } \\
{\left[\mathrm{km}^{2}\right]}\end{array}$ & $\begin{array}{c}\text { Potter } \\
\text { Penins. } \\
{\left[\mathrm{km}^{2}\right]}\end{array}$ & $\begin{array}{c}\text { Nelson } \\
\text { Island } \\
{\left[\mathrm{km}^{2}\right]}\end{array}$ & $\begin{array}{c}\text { Total ice } \\
{\left[\mathrm{km}^{2}\right]}\end{array}$ & $\begin{array}{c}\text { ee area } \\
{[\%]}\end{array}$ \\
\hline 1 & 4.9 & 0.2 & 0.6 & 1.3 & 0.6 & 7.7 & 13.9 \\
\hline 2 & 7.1 & 0.3 & 1.7 & 1.6 & 1.5 & 12.3 & 22.2 \\
\hline 3 & 4.9 & 0.1 & 0.4 & 1.0 & 0.6 & 7.0 & 12.6 \\
\hline 4 & 5.8 & 0.2 & 1.7 & 1.5 & 1.8 & 11.1 & 20.0 \\
\hline 5 & 3.8 & 0.8 & 2.9 & 1.2 & 0.9 & 9.6 & 17.4 \\
\hline 6 & 1.8 & 0.0 & 0.3 & 0.3 & 0.6 & 3.1 & 5.6 \\
\hline 7 & 2.1 & 0.0 & 1.1 & 0.9 & 0.4 & 4.6 & 8.3 \\
\hline Total $\left[\mathrm{km}^{2}\right]$ : & 30.5 & 1.7 & 8.8 & 7.8 & 6.6 & 55.3 & \\
\hline Total [\%]: & 55.2 & 3.0 & 15.9 & 14.1 & 11.9 & & 100.0 \\
\hline
\end{tabular}


In order to separate these different features using the RADARSAT-2 data and applying advanced polarimetric techniques for the ice-free areas it was important to have a thorough knowledge of the geomorphological processes that influence the structure of the different surface landforms. This was only really possible through field work by characterizing these surface landforms to obtain the corresponding training sites for the selected supervised classifier.

\section{Conclusions}

Characterizing and mapping surface landforms in ice-free areas are important tasks within a highly dynamic area such as the Antarctic Peninsula region.

Fieldwork and traditional geomorphological mapping have provided an overview of landforms characteristics and distribution in selected areas of the archipelago. Using SAR remote sensing techniques, seven terrain classes permit to characterize the different surface landforms. Class 1 corresponds to the present day and Holocene beaches; class 2 is defined by pavements, stone fields, patterned ground and nival landforms; class 3 is formed by stone fields, geometric clasts, laminated cracking or small tors; and class 4 is dominated by the patterned ground. These 4 classes are characterized by flats and gentle slopes with fines and coarse particles. The dominant processes are cryoturbation, frost heave, frost creep and frost cracking above $20 \mathrm{~m}$ a.s.l., the nivation and wind action at any altitude. Classes 1 to 4 are very heterogeneous and the processes distribution vary significantly over a small area, so they are the most unstable and dynamic classes. Class 5, which includes till deposits, rock outcrops and cliffs, forms a very heterogeneous topography shaped by ice cored moraine, exposed rock surfaces and debris cover on plains and slopes. Class 6, with lakes and poor drainage areas from sea level to the upper raised platforms, and class 7, with ice and snow on undulating gentle topography, determined by seasonal nivation processes, were easy to identify and are the most stable terrain with high ecological values.

SAR remote sensing techniques are of great advantage where meteorological conditions are harsh and direct accessibility in the field is often limited. Using RADARSAT-2 data and these techniques undertaken in this work, it has been possible to determine the surface land covers in ice-free areas around Maxwell Bay. Furthermore, these techniques will make it possible to compare past and future results and the evolution of areas affected by changing environmental factors and increasing human induced activities.

\section{Acknowledgements}

This work is supported by the project CTM2014-57119-R of the Spanish R\&D National Plan. The authors would like to gratefully thank and acknowledge the support of the Canadian Space Agency and MacDonald, Dettwiler and Associates for providing the satellite data by means of the Science and Operational Applications Research Program (SOAR) project SOAR-5169. Furthermore, the authors would like to thank the colleagues that participated in the different field campaigns, the Spanish logistic personnel, and the support provided by the Antarctic programs of other countries operating in the South Shetland Islands. 


\section{References}

Arche, A., López-Martínez, J., Serrano. E., Martínez de Pisón, E. 1996. Marine landforms and deposits. In J. López-Martínez, M.R.A. Thomson, J.W. Thomson (eds.), Geomorphological Map of Byers Peninsula, Livingston Island, BAS Geomap Series, 5-A, 35-42, Cambridge, British Antarctic Survey.

Balks, M.R., López-Martínez, J., Goryachkin, S., Mergelov, N., Schaefer, C., Simas, F., Almond, P., Claridge, G.C.G., Mcleod, M., Scarrow, J. 2013. Windows on Antarctic soil landscape relationships: comparison across selected regions of Antarctica. In M.J. Hambrey, P.F. Barker, P.J. Barrett, V. Bowman, B. Davies, J.L. Smellie, M. Tranter (eds.), Antarctic Palaeoenvironments and Earth-Surface Processes, Geological Society, Special Publications, London, pp. 397-410.

Bañón, M. 1992. El clima en las Shetland del Sur y el norte de la Península Antártica. Caso de la B.A.E. Juan Carlos I. La Meteorología II 7-8, 38-45.

Bañón, M., Justel, A., Velázquez, D., Quesada, A. 2013. Regional weather survey on Byers Peninsula, Livingston Island, South Shetland Islands, Antarctica. Antarctic Science 25, 146156.

Barker, P.F., Dalziel, I.W.D., Storey, B.C. 1991. Tectonic development of the Scotia Arc region. In R.J. Tingey (ed.), Antarctic Geology, Oxford University Press. Oxford, UK, pp. 215-248.

Baroni, C., Bruschi, G., López-Martínez, J. 1997. Review of Antarctic Geomorphological Mapping. Geografia Fisica e Dinamica Quaternaria 20, 15-31.

Barsch, D., Blümel, W.D., Flügel, W.A., Mäusbacher, R., Stäblein, G., Zick, W. 1985. UntersuchungenzumPeriglazial auf der König-Georg-Insel Süd Shetland Inseln/Antarktika. Deutsche physiogeographische Forschungen in der Antarktis. Berichtüber die Kampagne 1983/84. Reports on Polar Research, n 24 . Alfred Wegener Institute, Bremerhaven, Germany.

Bello, S., Bidegain, M., Lobato, H. 1996. Características Climatológicas de la Bahía Collins, Isla Rey Jorge, Antártida. Dirección General de Meteorología del Uruguay, Montevideo, 35 pp.

Bergamín, J.F., Durán, J.J., González-Casado, J.M., López-Martínez, J. 1997. Morfología y estructura del basamento precuaternario de la Caleta Española, Península Hurd, Isla Livingston. Boletín de la Real Sociedad Española de Historia Natural (Sección Geológica) 93 (1-4), 187-194.

Berkman, P.A., Andrews, J.T., Björck, S., Colhoun, E.A., Emslie, S.D., Goodwin, I.D., Hall, B.L., Hart, C.P., Hirakawa, K., Hjort, C., Igarashi, A., Ingólfsson, O., López-Martínez, J., Lyons, W.B., Mabin, M.C.G., Quilty, P.G., Taviani, M., Yoshida, Y. 1998. Circum-Antarctic coastal environmental shifts during the Late Quaternary reflected by emerged marine deposits. Antarctic Science 10 (3), 345-362.

Blümel, W.D., Eitel, B. 1989. Geoecological aspects of maritime-climatic and continental periglacial regions in Antarctica (S-Shetland, Antarctic Peninsula and Victoria Land). Geoökodynamic 10, 201-214.

Bockheim, J.G., Vieira, G., Ramos, M., López-Martínez, J., Serrano, E., Guglielmin, M., Wihelm, K., Nieuwendam, A. 2013. Climate Warming and Permafrost Dynamics on the Antarctic Peninsula Region. Global and Planetary Change 100, 215-223.

Bruschi, G., López-Martínez, J., Baroni, C. 1997. Los mapas geomorfológicos de la Antártida. Análisis comparativo. Boletín de la Real Sociedad Española de Historia Natural (Secc. Geol.) 93 (1-4), 195-203.

Campbell, I.B., Claridge, G.G.C. 1987. Antarctica: Soils, weathering processes and environment. Amsterdam, Elsevier.

Cannone, N., Guglielmin, M. 2010. Relationships between periglacial features and vegetation development in Victoria Land, continental Antarctica. Antarctic Science 22 (6), 703-713. 
CGE-UAM-UFRJ. Centro Geográfico del Ejército, Universidad Autónoma de Madrid and Universidad Federal de Río de Janeiro 2005. Isla Elefante / Elephant Island, Antártida. Mapa E. 1:50.000. Serie Cartografía Antártica. Centro Geográfico del Ejército, Madrid.

Cook, A.J., Fox, A.J., Vaughan, D.G., Ferrigno, J.G. 2005. Retreating Glacier Fronts on the Antarctic Peninsula over the Past Half-Century. Science 308, 541-544.

Cui, Z., Youyu, X., Gengnian, L. 1989. Antarctic periglacial environment and the formation mechanism of "sorted circles" in the Península Fildes. Proccedings International Symposium on Antarctic Research, Chinese Committee on Antarctic Research, Chinese Ocean Press, Beijing, pp 82-90.

Chen, J., Blume, H.P. 1999. Study on the Dynamics of Soil Moisture in an Ice-Free Area of the Fildes Peninsula, King George Island, the Maritime Antarctic. Polarforschung 66, 11-18.

Chen, J., Zitong, G., Blume, H.P. 2000. Soils of Fildes Peninsula, King George Island, the maritime Antarctic. Part 1, formation processes and pedogenetic particularities. Chinese Journal of Polar Science 11 (1), 25-38.

D'Hondt, O., Guillaso, S., Hellwich, O. 2013. Iterative bilateral filtering of polarimetric SAR data. IEEE Journal of Selected Topics in Applied Earth Observations and Remote Sensing 6, 1628-1639.

Dimitriadou, E., Hornik, K., Leisch, F., Meyer, D., Weingesse, A. 2005. E1071: Misc Functions of the Department of Statistics (e1071), TU Wien, Version 1.5-11. Available at: http://cran.rproject.org/ (last access: 18/02/2016).

Engeset, R.V., Weydahl, D.J. 1998. Analysis of glaciers and geomorphology on Svalbard using multitemporal ERS-1 SAR images. IEEE Trans. Geosci. Remote Sens. 36 (6), 1879-1887.

Foody, G.M., Mathur, A. 2004a. A relative evaluation of multiclass image classification by support vector machines. IEEE Trans. Geosci. Remote Sensing 42, 1336-1343.

Foody, G., Mathur, A. 2004b. Toward intelligent training of supervised image classifications: directing training data acquisition for SVM classification. Remote Sensing Environment 93 (1), 107-117.

Francelino, M.R., Schaefer, C.E.G.R., Simas, F.N.B., Filho, E.I.F., de Souza, J.J.L.L., Costa, L.M. 2011. Geomorphology and soils distribution under paraglacial conditions in an ice-free area of Admiralty Bay, King George Island, Antarctica. Catena 85, 194-204.

González-Casado, J.M., Giner, J., López-Martínez, J. 2000. Bransfield Basin, Antarctic Peninsula: not a normal back arc basin. Geology 28 (11), 1043-1046.

Guglielmin, M., DalleFratte, M., Cannone, N. 2014. Permafrost warming and vegetation changes in continental Antarctica. Environmental Research Letters 9, 045001, 14 pp.

Guillaso, S., Schmid, T., López-Martínez, J., D’Hondt, O. 2015. Application of a new polarimetric filter to RADARSAT-2 data of Deception Island (Antarctic Peninsula region) for surface cover characterization. The International Archives of the Photogrammetry, Remote Sensing and Spatial Information Sciences-ISPRS Archives Vol. XL-7/W3, 1035-1039.

Hall, B.L. 2009. Holocene glaciar history of Antarctica and sub-Antarctic Islands. Quaternary Science Reviews 28, 2213-2230.

Hall, B.L. 2010. Holocene relative sea-level changes and ice fluctuations in the South Shetland Islands. Global and Planetary Change 74, 15-26.

Hall, K. 1992a. Mechanical weathering on Livingston Island, South Shetland Islands, Antarctica. In Y. Yoshida, K. Kaminuma, K. Shiraishi (eds.), Recent Progress in Antarctic Earth Science, Terrapub, Tokyo, pp. 757-762.

Hall, K. 1992b. Mechanical weathering in the Antarctic. In J.C. Dixon, A.D. Abrahams (eds.), Periglacial Geomorphology, Wiley, Chichester, 103-123.

Hall, K. 1993. Enhanced bedrock weathering in association with late-lying snow patches: evidence from Livingston Island, Antarctica. Earth Surface Processes and Landforms 18, 121-129. 
Hsu, C.W., Chang, C.C., Lin, C.J. 2010. A practical guide to support vector classification. Department of Computer Science, National Taiwan University, Taipei, Taiwan, pp. 106. Available at: http://www.csie.ntu.edu.tw/ cjlin/libsvm (last access: 18/02/2016).

Jeong, G.Y. 2006. Radiocarbon ages of sorted circles on King George Island, South Shetland Island, West Antarctica. Antarctic Science 18 (2), 265-270.

Jezek, K.C. 1999. Glaciological properties of the Antarctic ice sheet from RADARSAT 1 synthetic aperture radar imagery. Annals of Glaciology 29, 286-290.

Jezek, K.C., Farness, K., Carande, R., Wu, X., Labelle-Hamer, N. 2003. RADARSAT 1 synthetic aperture radar observations of Antarctica: Modified Antarctic mapping mission, 2000. Radio Science 38 (4), 8067, M.32, 1-7.

John, B., Sugden, D.E. 1971. Raised marine features and phases of glaciation in the South Shetland Islands. British Antarctic Survey Bulletin 24, 45-111.

John, B.S., Sudgen, D.E. 1973. Raised marine features and phases of glaciation in the South Shetland Islands. British Antarctic Survey Bulletin 24, 45-111.

King, J.C., Turner, J. 1997. Antarctic Meteorology and Climatology. Cambridge University Press, Cambridge.

King, J.C., Comiso, J.C. 2003. The spatial coherence of Interannual temperature variations in the Antarctic Peninsula. Geophysics Research Letters 30 (2), 1040-1041.

Koch, M., López-Martínez, J., Schmid, T., Serrano, E., Gumuzzio, J. 2008. Application of ALOS PALSAR for the study of periglacial features related to permafrost within the South Shetland Islands, Western Antarctica. International Geoscience and Remote Sensing Symposium (IGARSS), Boston, USA. IEEE Vol. 4, pp. 343-346.

Koch, M., López-Martínez, J., Schmid, T., Serrano, E., Gumuzzio, J. 2009. Evaluating the use of ALOS data (microwave and optical) for mapping geomorphological features of selected areas in Livingston Island, South Shetland Islands (West Antarctica). ESA SP-664. Proceedings of ALOS PI 2008 Symposium, Rhodes, Greece, pp. 1-4.

Lee, J.S., Pottier, E. 2009. Polarimetric radar imaging: from basics to applications. CRC Press, Taylor \& Francis Group, Boca Raton.

López-Martínez, J., Serrano, E. 2002. Geomorphology of Deception Island. In J. López-Martínez, J.L. Smellie, J.W. Thomson, M.R.A. Thomson, M.R.A. (eds.), Geology and Geomorphology of Deception Island, BAS Geomap Series, Sheets 6-A and 6-B, British Antarctic Survey, Cambridge, pp. 31-39.

López-Martínez, J., Serrano, E., Lee, J.I. 2002a. Geomorphological Map of Barton and Weaver Peninsulas, King George Island, Antarctica. Korea Ocean Research and Development Institute, Seoul.

López-Martínez, J., Martínez de Pisón, E., Arche, A. 1992. Geomorphology of Hurd Peninsula. In Y. Yoshida, S. Kaminuma, Y. Shiraishi (eds.), Recent Progress in Antarctic Earth Science, Terrapub, Tokyo, pp. 751-756.

López-Martínez, J., Martínez de Pisón, E., Serrano, E., Arche, A. 1995. Geomorphological Map of Byers Peninsula, Livingston Island. BAS Geomap Series, Sheet 5-A, 1:25,000, 1996, British Antarctic Survey, Cambridge.

López-Martínez, J., Serrano, E., Martínez de Pisón, E. 1996a. Geomorphological features of the drainage system. In J. López-Martínez, M.R.A. Thomson, J.W. Thomson (eds.), Geomorphological Map of Byers Peninsula, Livingston Island, BAS Geomap Series, 5-A, 15-19, British Antarctic Survey, Cambridge.

López-Martínez, J., Serrano, E., Rey, J., Smellie, J.L. 2000. Geomorphological Map of Deception Island. BAS Geomap Series, Sheets 6-B, E. 1/25,000, 2002, British Antarctic Survey, Cambridge. 
López-Martínez, J., Serrano, E., Schmid, T., Mink, S., Linés, C. 2012. Periglacial processes and landforms in the South Shetland Islands (Northern Antarctic Peninsula region). Geomorphology 155-156, 62-79.

López-Martínez, J., Smellie, J.L., Thomson, J.W., Thomson, M.R.A. (eds.) 2002b. Geology and Geomorphology of Deception Island. BAS Geomap Series, Sheets 6-A and 6-B, British Antarctic Survey, Cambridge, 77 pp. +3 maps.

López-Martínez, J., Thomson, M.R.A., Thomson, J.W. (eds.) 1996b. Geomorphological Map of Byers Peninsula, Livingston Island. BAS Geomap Series, 5-A, British Antarctic Survey, Cambridge, 65 pp. +2 maps.

Magagi, R., Bernier, M. 2003. Optimal conditions for wet snow detection using RADARSAT SAR data. Remote Sensing of Environment 84, 221-233.

Martínez de Pisón, E., López-Martínez, J., Arche, A. 1991. Formas y depósitos de la zona de Johnsons Dock. Mapa geomorfológico. Isla Livingston, Shetland del Sur, Antártida. Ería 23, 39-43.

Martínez de Pisón, E., Serrano, E., Arche, A., López-Martínez, J. 1996. Glacial geomorphology. In J. López-Martínez, M.R.A. Thomson, J.W. Thomson (eds.), Geomorphological Map of Byers Peninsula, Livingston Island. BAS Geomap Series, 5-A, British Antarctic Survey, Cambridge, pp. 23-27.

Michalchuck, B.R., Anderson, J.B., Wellner, J.S., Manley, P.L., Majewski, W., Bohaty, S. 2009. Holocene climate and glacial history of the northeastern Antarctic Peninsula: the marine sedimentary record from a long SHALDRIL core. Quaternary Science Reviews 28, 30493065 .

Michel, R.F.M., Schaefer, C.E.G.R., Poelking, E.L., Simas, F.N.B., Fernandes, E.I., Bockheim, J.G. 2012. Active layer temperature in two Cryosols from King George Island, Maritime Antarctica. Geomorphology 155-156, 12-19.

Michel, R.F.M., Schaefer, C.E.G.R., Dias, L.E., Simas, F.N.B., Melo Benites, V., Sá Mendonça, E. 2006. Ornithogenic gelisols (Cryosols) from Maritime Antarctica. Soil Science Society of America Journal 70, 1370.

Michel, R.F.M., Schaefer, C.E.G.R., López-Martínez, J., Simas, F.N.B., Haus, N.W., Serrano, E., Bockheim, J.G. 2014. Soils and landforms from Fildes Peninsula and Ardley Island, Maritime Antarctica. Geomorphology 225, 76-86.

Milliken, K.T., Anderson, J.B., Wellner, J.S., Bohaty, S.M., Manley, P.L. 2009. High resolution Holocene climate record from Maxwell Bay, South Shetland Islands, Antarctica. Geological Society of America Bulletin 121, 1711-1725.

Mink, S., López-Martínez, J., Maestro, A., Garrote, J., Ortega, J.A., Serrano, E., Durán, J.J., Schmid, T. 2014. Insights into deglaciation of the largest ice-free area in the South Shetland Islands (Antarctica) from quantitative analysis of the drainage system. Geomorphology, 225, 4-24.

Mink, S., Maestro, A., J. López-Martínez, J., Schmid, T., Galindo-Zaldívar, J., Trouw, R.A.J. 2015. Morphostructural analysis and Cenozoic evolution of Elephant Island, Southern Scotia Arc, Antarctica. International Journal of Earth Sciences 104, 833-851.

Mora, C., Vieira, G., Ramos, M. 2013. Evaluation of Envisat ASAR IMP imagery for snow mapping at varying spatial resolution (Deception Island, South Shetlands, Antarctica). In Antarctic Palaeoenvironments and Earth Surface Processes, GSL Special Publication 381, Geological Society of London, London, pp. 481-493.

Moura, P.A., Francelino, M.R., Schaefer, C.E.G.R., Simas, F.N.B., Mendonça, B.A.F. 2012. Distribution and characterization of soils and landform relationships in Byers Peninsula, Livingston Island, Maritime Antarctica. Geomorphology 155-156, 45-54. 
Navas, A., López-Martínez, J., Casas, J., Machín, J., Serrano, E., Durán, J.J., Cuchí, J.A. 2006. Soil characteristics along a transect on raised marine surfaces on Byers Peninsula, South Shetland Islands. In D.K. Fütterer, D. Damaske, G. Kleinschmidt, H. Müller, F. Tessensohn (eds.), Antarctica. Contributions to Global Earth Sciences, Springer, Berlin, pp. 467-474.

Navas, A., López-Martínez, J., Casas, J., Machín, J., Durán, J.J., Serrano, E., Cuchí, J.A., Mink, S. 2008. Soil characteristics on varying lithological substrates in the South Shetland Islands, Maritime Antarctica. Geoderma 144, 123-139.

Oliva, M., Ruiz-Fernández, J. 2015. Coupling patterns between paraglacial and permafrost degradation responses in Antarctica. Earth Surface Processes and Landforms. Doi: 10.1002/ esp.3716.

Oliva, M., Ruiz-Fernández, J. 2016. Geomorphological processes and frozen ground conditions in Elephant Point (Livingston Island, South Shetland Islands, Antarctica). Geomorphology. Available at: http://dx.doi.org/10.1016/j.geomorph.2016.01.020.

Pereira, A.B., Putzke, J. 2013. The Brazilian research contribution to knowledge of the plant communities from Antarctic ice free areas. Anais da Academia Brasileira de Ciências, 85 (3), 923-935.

Pottier, E. 2010. Recent advances in the development of the open source toolbox for polarimetric and interferometric polarimetric SAR data processing: the PolSARpro v4.1.5 software. International Geoscience and Remote Sensing Symposium (IGARSS), IEEE, Honolulu, Hawaii, USA, pp. 2527-2530.

Qingsong, Z. 1989. A comparison of periglacial landforms between the Vestfold Hills, East Antarctica and the Fildes Península of King George Island, west Antarctica. Proccedings International Symposium on Antarctic Research, Chinese Committee on Antarctic Research, Chinean Ocean Press, Beijing, 74-81.

R Development Core Team 2004. A Language and Environment for Statistical Computing. $R$ Foundation for Statistical Computing, Vienna, Austria. Available at: http: //www.R-project. org/.

Rakusa-Suszczewski, S. (ed.) 1993. The Maritime Antarctic Coastal Ecosystem of Admiralty Bay. Department of Antarctic Biology, Polish Academy of Sciences, Warsaw, 216 pp.

Rakusa-Suszczewski, S. 2002. King George Island-South Shetland Island, Maritime Antarctic. In L. Beyer, M. Bölter (eds.), Geoecology of Antarctic Ice Free Coastal Landscapes, Springer Verlag, Berlín, pp. 23-40.

Rasmussen, E.A., Turner, J. 2003. Polar Lows: Mesoscale Weather Systems in the Polar Regions. Cambridge University Press, Cambridge, 624 pp.

S1TBX 2014. Sentinel-1 Toolbox. Array Systems Computing Inc. and contributers. Available at: https://sentinel.esa.int/web/sentinel/toolboxes/sentinel-1 (last access: 18/02/2016).

Schaefer, C.E.G.R., Simas, F.N.B., Gilkes, R.J., Mathison, C., Costa, L.M. 2007. Micromorphology and microchemistry of Cryosols from Maritime Antarctica. Geoderma 144, 104-115.

Schmid, T., López-Martínez, J., Koch, M., Maestro, A., Serrano, E., Linés, C. 2012. Geomorphological mapping in the Antarctic Peninsula region applying single and multipolarization RADARSAT-2 data. Canadian Journal of Remote Sensing 38 (3), 367-382.

Schmid, T., López-Martínez, J., Guillaso, S., D’Hondt, O., Koch, M., Mink, S., Nieto, A., Serrano, E. 2015. Distribution of glacial and periglacial features within ice-free areas surrounding Maxwell Bay (South Shetland Islands) using polarimetric RADARSAT-2 data. IGARSS IEEE International, pp. 3458-3461.

Schwerdtfeger, W. 1970. The climate of Antarctica. In H.E. Landsberg (ed.), World Survey of Climatology, Orvig Editor, Amsterdam, pp. 253-355.

Serrano, E., Martínez de Pisón, E., López-Martínez, J. 1996. Periglacial and nival landforms and deposits. In J. López-Martínez, M.R.A. Thomson, J.W. Thomson (eds.), Geomorphological 
Map of Byers Peninsula, Livingston Island, Bas Geomap Series, Sheet 5-A, 1:25,000, with Supplementary Text, British Antarctic Survey, Cambridge, pp. 28-34.

Serrano, E., López-Martínez, J. 1997a. Geomorfología de la Península Coppermine, Isla Robert, Islas Shetland del Sur. Serie Científica INACH 47, 19-29.

Serrano, E., López-Martínez, J. 1997b. Evolución de las formas del relieve y los depósitos superficiales cuaternarios en la Isla Media Luna, Islas Shetland del Sur. Boletín de la Real Sociedad Española de Historia Natural (Sección Geológica) 93 (1-4), 205-216.

Serrano, E., López-Martínez, J. 1998. Caracterización y distribución de las formas y los procesos periglaciares en las Islas Shetland del Sur, Antártida. In A. Gómez, F. Salvador, L. Schulte, A. García, (eds.), Procesos biofísicos actuales en medios fríos, Publicaciones de la Universidad de Barcelona, Barcelona, pp. 181-204.

Serrano, E., López-Martínez, J. 2000. Rock glaciers in the South Shetland Islands, Western Antarctica. Geomorphology 35, 145-162.

Serrano, E., López-Martínez, J. 2004. Morfogénesis periglaciar y deglaciación en las penínsulas Barton y Weaver (islas Shetland del Sur, Antártida). Boletín de la Real Sociedad Española de Historia Natural (Sección Geológica), 99 (1-4), 131-140.

Serrano, E., Giner, J., Gumiel, P., López-Martínez, J. 2002a. Morfodinámica de laderas en las Islas Shetland del Sur, Antártida Marítima. In E. Serrano, A. García (eds.), Periglaciarismo en montaña y altas latitudes, Universidad de Valladolid, Valladolid, pp. 231-255.

Serrano, E., Giner, J., Gumiel, P., López-Martínez, J. 2002b. Permafrost en las Islas Shetland del Sur (Antártida Marítima). Distribución y dinámica actual. In E. Serrano, A. García (eds.), Periglaciarismo en montaña y altas latitudes, Universidad de Valladolid, Valladolid, pp. 277296.

Serrano, E., López-Martínez, J. 2012. Geomorphological Mapping in Antarctic Periglacial Environment. The Geomorphological Map of Fildes Península (King George Island, South Shetlands Archipelago). Proceedings of the Tenth International Conference on Permafrost, Volume 4, IPA-Tyumen State Oil and Gas University, Tyumen, Russia, pp. 521-518.

Serrano, E., López-Martínez, J., Cuchí, J.A., Durán, J.J., Mink, S., Navas, A. 2008. Permafrost in the South Shetland Islands (Maritime Antarctica): spatial distribution pattern. In D.L. Kane, K.M. Hindel (eds.), Ninth International Conference on Permafrost, Institute of Northern Engineering, University of Alaska Fairbanks, Fairbanks, Alaska, pp. 1621-1625.

SGE-UAM, Servicio Geográfico del Ejército, Universidad Autónoma de Madrid 1993. Isla Decepción/Deception Island, Antártida. Mapa E. 1:25,000, Serie Cartografía Antártica, Madrid, Servicio Geográfico del Ejército, Madrid.

SGE-UAM-BAS, Servicio Geográfico del Ejército, Universidad Autónoma de Madrid, British Antarctic Survey 1992. Mapa Topográfico E. 1:25,000, Península Byers/ByersPeninsula, Isla Livingston, Antártida. Serie Cartografía Antártica, Servicio Geográfico del Ejército, Madrid.

Simas, F.N.B., Schaefer, C.E.G.R., Melo, V.F., Guerra, M.B.B., Saunders, M., Gilkes, R.J. 2006. Clay-sized minerals in permafrost-affected soils (Cryosols) from King George Island, Antarctica. Clays and Clay Mineralogy 54, 721-736.

Simas, F.N.B., Schaefer, C.E.G.R., Melo, V.F., Albuquerque-Filho, M.R., Michel, R.F.M., Pereira, V.V., Gomes, M.R.M., Da Costa, L.M. 2007. OrnithogenicCryosols from Maritime Antarctica: phosphatization as a soil forming process. Geoderma 138, 191-203.

Simas, F.N.B., Schaefer, C.E.G.R., Albuquerque-Filho, M.R., Francelino, M.R., Fernades-Filho, E.I., Da Costa, L.M. 2008. Genesis, properties and classification of Cryosols from Admiralty Bay, Maritime Antarctica. Geoderma 144, 116-122. 
Simas, F.N.B., Schaefer, C.E.G.R., Michel, R.F.M., Francelino, M.R., Bockheim, J.G. 2015. Soils of the South Orkney and South Shetland Islands, Antarctica. In J.G. Bockheim (ed.), The Soils of Antarctica, Springer, Berlin, pp. 227-273.

Simonov, I.M. 1977. Physical-geographic description of the Fildes Peninsula (South Shetland Islands). Polar Geography 1, 223-242.

Smellie, J.L., Pankhurst, R.J., Thomsom, M.R.A., Davies, R.E.S. 1984. The Geology of the South Shetland Island. VI. Stratigraphy, Geochemistry and Evolution. British Antarctic Survey Scientific Reports, No. 87. British Antarctic Survey, Cambridge, 85 pp.

Sugden, D.E., John, B.S. 1973. The ages of glacier fluctuations in the South Shetland Islands, Antarctica. In E.M. van Zinderen Bakker (ed.), Paleoecology of Africa, the surrounding islands and Antarctica, A.A. Balkema, Cape Town, pp. 141-159.

Tin, T., Liggett, D., Maher, P.T., Lamers, M. 2014. Antarctic Futures. Human Engagement with the Antarctic Environment. Springer.

Toro, M., Granados, I., Pla, S., Giralt, S., Antoniades, D., Galán, L., Martínez-Cortizas, A., Lim, H.S., Appleby, P.G. 2013. Chronostratigraphy of the sedimentary record of Limnopolar Lake, Byers Peninsula, Livingston Island, Antarctica. Antarctic Science 25, 198-212.

Turner, J., Colwell, S.R., Marshall, G.J., Lachlan-Cope, T.A., Carleton, A.M., Jones, P.D., Lagun, V., Reid, P.A., Iagovkina, S. 2005. Antarctic climate change during the last 50 years. International Journal of Climatology 25, 279-294.

Vaughan, S., Edelson, R., Warwick, R.S., Uttley, P. 2003. On characterizing the variability properties of X-ray light curves from active galaxies. Monthly Notices of the Royal Astronomical Society 345 (4), 1271-1284.

Vieira, G., López-Martínez, J., Serrano, E., Ramos, M. 2008. Climate change and permafrost degradation. Geomorphological evidence from Deception and Livingston islands, Maritime Antarctic. In D.L. Kane, K.M. Hindel (eds.), Proceedings Ninth International Conference on Permafrost, Institute of Northern Engineering, University of Alaska Fairbanks, Fairbanks, Alaska, pp. 1839-1844.

Vieira, G., Bockheim, J., Guglielmin, M., Balks, M., Andrey, A., Boelhouwers, J., Cannone, N., Ganzer, L., Gilchinsky, D., Goryachkin, S., López-Martínez, J., Meiklejohn, I., Raffi, R., Ramos, M., Schaefer, C., Serrano, E., Simas, F., Sletten, R., Wagner, D. 2010. Thermal state of Antarctic permafrost and active-layer dynamics: Advances during the International Polar Year 2007-2008. Permafrost and Periglacial Processes 21, 182-197.

Vieira, G., Mora, C., Pina, P., Schaefer, C. 2014. A proxy for snow cover and winter ground surface cooling: mapping Usnea sp. communities using high resolution remote sensing imagery (Maritime Antarctica). Geomorphology 225, 69-75.

Vtyurin, B.I., Moskalevskiy, M.Y. 1985. Cryogenic landforms on King George Island, South Shetland Islands. Polar Geography and Geology 9 (1), 62-69.

Watcham, E.P., Bentley, M.J., Hodgson, D.A., Roberts, S.J., Fretwell, P.T., Lloyd, J.M., Larter, R.D., Whitehouse, P.L., Leng, M.J., Monien, P., Moreton, S.G. 2011. A new relative sea level curve for the South Shetland Islands, Antarctica. Quaternary Science Reviews 30, 3152-3170.

Xie, Y. 1988. Chemical weathering in permafrost regions of Antarctica. Great Wall Station of China, Casey Station and Davis Station of Australia. Fifth International Conference, Proceeding, Trondheim, pp. 511-515.

Ye, Z., Tianjie, L. 1996. The pedogenic groups and diagnostic characteristics in Fildes Peninsula of King George Island, Antarctica. Antarctic Research 7 (1), 70-78.

Zhu, C., Cui, Z., Zhang, J. 1996. Relationship between the distribution of periglacial landforms and glaciation history, Fildes Peninsula, King George Island, Antarctica. Permafrost and Periglacial Processes 7, 95-100. 